\title{
PEMBELAJARAN DAN PELATIHAN SENI KARINDING DI KABUPATEN CIAMIS SEBAGAI UPAYA PELESTARIAN BUDAYA LELUHUR SUNDA
}

\author{
Agus Nero Sofyan, Kunto Sofianto, Maman Sutirman, dan Dadang Suganda \\ Fakultas Ilmu Budaya Universitas Padjadjaran \\ E-mail: agus.nero@unpad.ac.id
}

\begin{abstract}
ABSTRAK. Pengabdian kepada masyarakat dengan judul "Pembelajaran dan Pelatihan Seni Karinding di Kabupaten Ciamis, Provinsi Jawa Barat sebagai Upaya Pelestarian Budaya Leluhur Sunda" dilaksanakan di Desa Winduraja, Kecamatan Kawali, Kabupaten Ciamis. Kegiatan ini bertujuan meningkatkan pemahaman masyarakat, terutama para siswa, para petani, dan karang taruna, tentang pentingnya pengetahuan tentang seni di Kabupaten Ciamis untuk melestarikan budaya Sunda. Pengabdian kepada masyarakat ini dilaksanakan dalam bentuk penyuluhan seni karinding di Ciamis. Dalam pelaksanannya, pengabdian ini bekerja sama dengan pemerintah daerah dan Karang Taruna. Metode yang digunakan dalam pengabdian ini adalah metode ceramah dan tanya jawab. Materi yang diberikan dalam pengabdian masyarakat ini adalah seni tradisional leluhur masyarakat Ciamis, yaitu seni karinding. Sumber data yang digunakan adalah menampilkan narasumber yang kompeten dalam bidang seni karinding sebagai data primer dan kajian pustaka sebagai data sekunder. Hasil yang dicapai dalam pengabdian ini adalah bahwa masyarakat Ciamis masih memelihara/melestarikan seni karinding sehingga bisa dijadikan satu di antara budaya leluhur di Ciamis.
\end{abstract}

Kata Kunci: pembelajaran, pelatihan, seni, karinding, Ciamis, budaya

\section{PENDAHULUAN}

Kompleksitas kultural yang ada di Indonesia menjadi cerminan kemajemukan kehidupan masyarakat pendukungnya. Kemajemukan yang ada diperlihatkan dengan adanya keanekaragaman budaya, lingkungan, alam, dan wilayah geografis. Dalam kaitannya dengan keanekaragaman budaya, masyarakat Indonesia telah memperlihatkan adanya keragaman seni tradisional yang tersebar di berbagai daerah, termasuk di dalamnya adalah kerajian tangan tradisional. Keanekaragaman kerajinan ini menjadi satu di antara aset intelektual yang berhubungan dengan sosiokultural yang mesti dilestarikan dan dikembangkan. Sebagai satu aspek di antara tujuh unsur kebudayaan, kesenian tradisional lahir, tumbuh, dan berkembang di tengah-tengah kehidupan masyarakat pendukungnya. Kesenian merupakan milik bersama dari suatu kelompok sosial dan menjadi cerminan sistem nilainya (Susanto, 1983).

Dalam konteks kajian budaya yang lebih luas, kesenian tradisional menjadi satu di antara unsur kebudayaan yang bisa dijadikan sebagai subkajian utama. Kajian mengenai kesenian tradisional dengan seperangkat nilai estetiknya bukanlah sesuatu yang monolitis. Keberadannya sangat berhubungan erat dengan unsurunsur pokok lainnya, seperti religi, ekonomi, struktur sosial, dan sebagainya. Nilai estetik dalam kerajinan tangan tradisional merupakan fenomena tanda implisit yang berhubungan dengan konstruksi yang lebih besar, yaitu kebudayaan dalam makna yang lebih umum. Hal ini senada dengan apa yang diungkapkan oleh Sumardjo bahwa nilai estetik seni adalah fenomena sensoris yang mengandung makna implisit (Sumardjo, 2006).

Proses regenerasi melalui pendidikan indeginius menjadi penting dalam proses penjagaan dan pelestarian kekayaan intelektual berbasis kearifan lokal di wilayah manapun. Kondisi ini akan menjadi dilema jika dalam proses regenerasinya, minim sumbangsih dari pihak- pihak terkait, seperti praktisi kerajinan berbasis kearifan lokal, para perajin, pemerintah daerah, dan sebagainya. Minimnya kesadaran kultural dari para praktisi kerajinan, misalnya, tentu akan berdampak pada kurangnya proses regenerasi dari generasi tua kepada generasi muda. Oleh sebab itu, posisi kesadaran kultural dan kepekaan nalar untuk menjaga dan melestarikan kearifan lokal menjadi penting adanya. Apabila hal itu diabaikan, maka proses pelestarian keterampilan berbasis kearifan lokal akan terhambat. Hal ini senada dengan apa yang diungkapkan Gunardi bahwa pada saat ini pemertahanan kehidupan budaya dan tradisi masyarakat Sunda sedikit demi sedikit mulai termarginalkan (Gunardi, 2014). Dalam kondisi demikian, peran peneliti budaya pun tidak kalah pentingnya dalam proses pelestarian dan pendokumentasian budaya lokal yang ada di suatu wilayah tertentu. Hal ini seperti yang disampaikan Wikandia bahwa penelitin secara tidak langsung telah membantu pelestarian budaya lokal (Wikandia, 2016).

Jawa Barat merupakan wilayah yang diidentikan dengan budaya Sunda. Ketika berbicara mengenai budaya Jawa Barat, identitas yang muncul adalah Sunda. Hal ini disebabkan oleh masyarakat Sunda menempati sebagian besar wilayah Jawa Barat, yaitu Bekasi, Depok, Bogor, Sukabumi, Cianjur, Karawang, Subang, Purwakarta, Cimahi, Bandung, Garut, Sumedang, Indramayu, Majalengka, Cirebon, Kuningan, Ciamis, Tasikmalaya, Pangandaran, dan Banjar. Sebagai bagian dari wilayah Indonesia, Jawa Barat telah memberikan sumbangsih kultural berupa kebudayaan lokal dan tradisional yang lahir dan berkembang di daerahdaerah tersebut. Satu di antara wilayah Jawa Barat yang memiliki sumbangan besar dalam mengembangkan kebudayaan tradisional Jawa Barat adalah Kabupaten Ciamis.

Masyarakat Sunda di Ciamis tentu memiliki seni yang khas dan berkarakter. Seni-seni tersebut meliputi seni rupa (gambar, patung, tekstil, dan keramik), seni pertunjukan (musik, tari, dan teater), seni sastra (prosa dan 
puisi, lisan dan tertulis), dan seni media rekam (Sedyawati, 2006). Selain itu, ada juga seni kriya (kerajinan tangan) dan seni bela diri. Kesenian yang dijadikan kajian pada kesempatan kali ini adalah kesenian karinding yang merupakan satu di antara kesenian ikonik Ciamis.

Jenis seni tersebut merupakan potensi budaya yang dimiliki oleh masyarakat Kabupaten Ciamis dan mutlak harus dilestarikan. Upaya-upaya pelestarian tentu tidak mudah dilakukan karena pesatnya perkembangan zaman, adanya globalisasi, serta kemajuan di bidang teknologi, komunikasi, dan informasi. Hal tersebut ditengarai menjadi faktor penyebab mulai lunturnya nilai-nilai budaya dalam suatu masyarakat. Warisan adiluhung yang dimiliki oleh masyarakat Sunda perlahan-lahan terkikis dan mulai ditinggalkan masyarakat yang kemudian terganti oleh kebudayaan baru yang dianggap modern. Namun, masih terdapat beberapa anggota masyarakat yang berupaya mengembangkan, mempertahankan, dan melestarikan seni yang dimiliki mereka dengan harapan dapat terus dinikmati dan diteruskan oleh anak cucu mereka, yaitu generasi selanjutnya.

Seni music, secara umum, lahir dan berkembang di berbagai kepulauan Indonesia. Seni yang satu ini menjadi kebiasaan di masyarakat yang diberikan secara turuntemurun kepada anak cucu sehingga kehadirannya masih tetap ada sampai saat ini. Hal menarik dari seni musik ini selain dari segi musiknya (seperti karawitan, keroncong, dangdut dan sebagainya) juga dari segi alat musiknya. Alat musik yang digunakan dalam seni musik daerah biasanya berupa alat musik tradisional.

Karinding adalah satu di antara alat musik tradisional Jawa Barat yang kehadirannya patut dipertimbangkan karena karinding ini mempunyai keunggulan dari karinding lainnya, keunggulan tersebut dapat menjadi daya tarik bagi dunia. Oleh karena itu, pada pengabdian kepada masyarakat ini akan dibahas mengenai alat musik tradisional karinding sebagai upaya mengenalkan serta melestarikannya serta sebagai bukti budaya leluhur masyarakat Sunda, khususnya di Kabupaten Ciamis, Provinsi Jawa Barat.

Berkaitan dengan uraian tersebut dapat diidentifikasikan permasalahan-permasalahan sebagai berikut: (a) bagaimanakah cara penginventarisasikan seni karinding di Ciamis, (b) apa saja model pentransferan seni karinding di Ciamis, (c) bagaimanakah cara-cara melestarikan seni karinding di Ciamis, dan (d) bagaimanakah kebijakan pemerintah daerah dalam peningkatan kualitas.

Terkait dengan identifikasi masalah tersebut dalam pengabdian masyarakat ini diusulkan upaya untuk peningkatan kualitas dan pelestarian seni karinding adalah sebagai berikut: (a) pengemasan seni yang komprehensif, (b) regenerasi pelaku seni yang berkesinambungan, (c) diakomodasikan dalam perda, dan (d) dipromosikan secara regional, nasional, dan internasional, serta dialokasikan dana rutin dari pemda.

\section{METODE}

Materi penyuluhan berorientasi pada upaya memupuk kesadaran masyarakat untuk mejaga dan melestarikan aset intelektual berupa kesenian karinding dan mengembangkannya menjadi kesenian ikonik Kabupaten Ciamis yang pada masanya nanti bisa dijadikan sebagai maskot dan daya tarik budaya di wilayah Ciamis. Pada prinsipnya, masyarakat dibina agar terbentuk kesadaran penuh bahwa mereka merupakan bagian integral untuk mengembangkan kesenian karinding. Keterkaitan unsur-unsur yang ada di Kabupaten Ciamis, baik secara langsung maupun tidak langsung, seperti pelaku seni, budayawan, pemerintah daerah, dan pegelola kesenian karinding dihubungkan secara komunikatif agar terbentuk koordinasi utuh untuk mengembangkan kesenian karinding di Kabupaten Ciamis.

Materi yang diberikan dalam pengabdian masyarakat ini adalah seni tradisional leluhur masyarakat Ciamis, yaitu seni karinding. Sumber data yang digunakan adalah menampilkan narasumber yang kompeten dalam bidang seni karinding sebagai data primer dan kajian pustaka sebagai data sekunder.

Secara keseluruhan, pengabdian kepada masyarakat ini dilaksanakan dalam bentuk penyuluhan seni karinding di Kabupaten Ciamis. Dalam pelaksanannya, pengabdian ini bekerja sama dengan pemerintah daerah dan karang taruna di Desa Minduraja, Kecamatan Kawali, Kabupaten Ciamis.

\section{Tabel 1. Tahapan Kegiatan Pengabdian Kepada Masyarakat}

\begin{tabular}{|c|c|c|c|c|}
\hline \multirow{2}{*}{ No. } & \multirow{2}{*}{ Rencana Kegiatan } & \multicolumn{3}{|c|}{ Keterlibatan dalam kegiatan } \\
\hline & & Dosen & Mahasiswa & Masyarakat \\
\hline 1 & survei lapangan & $\begin{array}{l}\text { memberikan arahan pedoman } \\
\text { kerja }\end{array}$ & $\begin{array}{l}\text { mendokumentasikan berbagai } \\
\text { kegiatan }\end{array}$ & $\begin{array}{l}\text { memberikan informasi yang } \\
\text { diperlukan }\end{array}$ \\
\hline 2 & menginven-tarisasi & mengkaji hasil dari inventarisasi & $\begin{array}{l}\text { meyusun dan } \\
\text { mendokumentasikan hasil } \\
\text { analisis }\end{array}$ & memberikan masukan \\
\hline 3 & $\begin{array}{l}\text { mewujudkan model } \\
\text { pentransferan }\end{array}$ & memberikan contoh role model & mengimprovisasikan & melaksanakan/mempraktikkan \\
\hline 4 & mengupayakan pelestarian & memberikan metode dan teknik & $\begin{array}{l}\text { membantu } \\
\text { mengimplementasikan }\end{array}$ & mengapresiasikan \\
\hline
\end{tabular}


Tabel 2. Indikator keberhasilan kegiatan (utama dan penunjang)

\begin{tabular}{|c|c|c|c|}
\hline No. & Indikator & $\begin{array}{l}\text { Base Line } \\
\text { (sebelum } \\
\text { kegiatan) }\end{array}$ & $\begin{array}{c}\text { Pencapaian } \\
\text { Setelah } \\
\text { Kegiatan }\end{array}$ \\
\hline 1 & $\begin{array}{l}\text { adanya eksistensi } \\
\text { seni karinding di } \\
\text { Kabupaten Ciamis }\end{array}$ & $\begin{array}{l}\text { mendapatkan } \\
\text { informasi yang } \\
\text { baik tentang data } \\
\text { yang diperlukan }\end{array}$ & $\begin{array}{l}\text { munculnya } \\
\text { kesadaran dari } \\
\text { masyarakat, } \\
\text { terutama } \\
\text { generasi muda, } \\
\text { dan pelaku } \\
\text { seni dalam } \\
\text { peningkatan } \\
\text { dan pelestarian } \\
\text { seni karinding } \\
\text { di Kabupaten } \\
\text { Ciamis }\end{array}$ \\
\hline
\end{tabular}

\section{HASIL DAN PEMBAHASAN}

Pengabdian kepada Masyarakat ini dilaksanakan di Desa Winduraja, Kecamatan Kawali, Kabupaten CiamisJawa Barat. Sebanyak 30 orang hadir sebagai peserta pelatihan yang berasal dari kalangan pelajar, petani, dan pemuda karang taruna. Dalam pelaksanaannya, para dosen (tim pengabdian) memberikan penyuluhan dan pelatihan tentang pentingnya masyarakat Ciamis untuk menjaga dan melestarikan satu di antara kekayaan intelektual yang ada di daerahnya, yaitu seni musik karinding.

Adapun permasalahan yang dihadapi oleh mitra adalah sebagai berikut: (a) engetahuan masyarakat di Desa Winduraja, Kecamatan Kawali, Kabupaten Ciamis terhadap kesenian karinding sangat rendah dan (b) masyarakat di Desa Winduraja, Kecamatan Kawali, Kabupaten Ciamis membutuhkan pengenalan tentang kesenian musik karinding sebagai upaya pelestarian kesenian tersebut.

\section{Seni Musik Karinding sebagai Kebudayaan Ikonik Kabupaten Ciamis}

Kesenian karinding yang ada di Dusun Margajaya, Desa Winduraja, Kecamatan Kawali Kabupaten Ciamis, secara historis, telah ada dan berkembang sejak zaman Kerajaan Pasundan. Awal mula kemunculan karinding, secara fungsional, karinding tidak dijadikan sebagai satu di antara perlengkapan kesenian, tetapi dijadikan sebagai alat yang difungsikan untuk berkomunikasi. Dalam tinjauan historis, kemunculan karinding pertama kali dibuat oleh Putra Kawandaka yang digunakan untuk memberi isyarat atau simbol kepada Putri Sekar Wati bahwa Putra Kawandaka ingin bertemu dengannya.

Seiring berjalannya waktu, fungsi karinding kemudian berubah menjadi satu di antara perlengkapan alat kesenian yang ikonik dan khas dalam kehidupan masyarakat Ciamis. Hal tersebut disebabkan karena kesenian karinding kerap kali digunakan oleh masyarakat Sunda zaman dulu ketika proses penggarapan padi. Pada masa itu, karinding juga berfungsi sebagai media untuk mengusir hama-hama yang menyerang padi. Adanya penggeresan fungsi karinding dari alat komunikasi/ pemberi sinyal menjadi sebuah alat kesenian, tentu tidak serta merta menghilangkan ciri khas dari cara pemakaiannya. Cara pemakaian karinding dari dulu, sejak kelahiran dan kemunculannya, hingga sekarang masih tetap sama, yaitu dengan cara ditiup.

Dalam konteks sosial budaya, kesenian karinding dipandang sebagai satu di antara alat kesenian yang identik dengan lokalitas, kulturalitas, dan dekat dengan alam. Hal ini terlihat dari penggunaan bambu (yang identik dengan alam) sebagai bahan dasar pembuatannya. Bambu yang digunakan sebagai bahan dasar pembuatan karinding bukan sembarang bambu, biasanya berjenis bambu pitu, bambu bombing, dan bambu haur. Namun, karinding yang pertama kali dibuat pada zaman dulu menggunakan bambu jenis aren. Meskipun terbuat dari bambu, hal tersebut tidak serta merta mengurangi nilai estetis dari suara yang dihasilkan karinding. Suara musik yang dihasilkan dari kesenian karinding tergolong ke dalam jenis musik ritmis. Setiap kali ada pementasan kesenian karinding, sudah secara otomatis akan disertai dengan suara-suara melodinya sebagai pengiringnya. Secara fungsional, karinding juga dapat digunakan sebagai pengiring berbagai jenis musik, seperi musik rege, pop, dangdut, dll. Penggunaanya bergantung pada kelihaian dan kecerdasan pemainnya.

Di balik bentuknya yang sederhana, karinding ternyata memiliki nilai filosofis yang tinggi. Bentuk karinding terbagi menjadi tiga bagian. Bagian pertama adalah pancepengan, yaitu bagian yang mesti dipegang dengan mantap pada saat memainkannya. Bagian kedua adalah cecet ucing, tempat buluh bambu karinding yang dibuat kecil dan tipis akan bergetar dan menghasilkan bunyi ketika bagian ketiga atau dikenal juga sebagai bagian paneunggeulan ditabuh. Jika ketiga bagian karinding sudah bisa dikuasai dengan baik oleh seniman karinding, ketika karinding ditabuh dan dirapatkan ke mulut, akan tercipta bunyi karinding yang mantap.

Pancepengan menjadi bagian pada alat musik karinding yang harus dipegang oleh pemain dengan baik dan benar. Tidak terlalu erat, yang penting pegangannya pas dan mantap. Secara filosofis, bagian ini mengandung makna bahwa pemain karinding harus memiliki keyakinan yang mantap dengan apa yang dipegangnya sebelum ia memainkannya. Sikap yakin juga tercita dari filosofis tersebut, yakni yakin dengan mantap bahwa ia mampu memainkannya dengan benar, yakin pula bahwa apa yang dimainkannya akan bermanfaat bagi khalayak umum, yakin kepada diri sendiri bahwa ia akan mampu meniupkan energi positif bagi individu. Dengan seperti itu, ia akan memupuk semangat awal dalam bermian karinding.

Kesenian musik karinding biasa dimainkan oleh orang-orang di perkampungan dengan sambil menunggu sawah atau ladang di hutan atau di bukit-bukit; saling bersahutan antara bukit yang satu dengan bukit lainnya. 
Alat musik ini tidak hanya berfungsi sebagai pengusir sepi, tetapi juga berfungsi pengusir hama. Suara yang dihasilkan oleh karinding ternyata mengandung gelombang low decibel yang menyakitkan hama, sehingga mereka akan menjauhi ladang pertanian.

\section{Upaya Pelestarian Kesenian Karinding di Kabupaten Ciamis}

Sebagai satu di antara kerajinan tangan tradisional ikonik Kabupaten Ciamis, karinding harus terus dijaga dan dilestarikan. Keberadannya sebagai aset intelektual yang berhubungan dengan pengetahuan tradisional, kerajinan tangan ini sedikit-banyaknya telah memberikan sumbangsih kultural dalam meningkatkan daya tarik wisata (khususnya dalam hal penyediaan souvenir), ekonomis, dan kultural di Kabupaten Ciamis. Akan tetapi, fakta di lapangan terungkap bahwa regenerasi pegiat kesenian karinding mengalami kendala. Hal ini tampak bahwa generasi penerus (putra-putri dari para pegiat seni) tidak/kurang tertarik untuk mengikuti jejak orang tuanya sebagai pegiat seni karinding.

Secara keseluruhan, sesuai dengan temuan yang ada di lapangan, penyebab luntur dan berkurangnya kesenian tradisional yang ada di Kabupaten Ciamis terbagi menjadi dua penyebab utama, yaitu penyebab umum dan penyebab khusus. Penyebab umum berkaitan dengan faktor-faktor yang menyebabkan kemunduran kehidupan kultural kesenian tradisional secara umum. Adapun sebab khusus merupakan penyebab yang hanya berkaitan dengan aspek kemunduran kesenian tradisional tersebut.

Dalam kaitannya dengan kondisi perubahan zaman dan hakikat kehidupan manusia, manusia secara umum mempunya kecenderungan untuk selalu merasa penasaran dengan hal-hal yang baru. Rasa kepenasaranan tersebut, pada masanya nanti akan mendorong manusia untuk menemukan hal-hal baru yang dianggap bermanfaat dan mengakomodasi kebutuhan dan keperluan kehidupannya. Hal-hal baru yang ditemukan tersebut diekspresikan dalam bentuk yang dikenal sebagai kreativitas. Dalam kaitannya dengan kehidupan budaya, daya kreativitas inilah yang menjadikan manusia sebagai makhluk yang berbudaya. Daya kreativitas ini pula yang menyebabkan keidupan budaya semakin dinamis, berkembang, maju, berubah, dan terus menyesuaikan dengan kondisi zaman yang baru. Perubahan itu pula dapat ditemukan dalam kehidupan kesenian tradisional di Kabupaten Ciamis.

Kesenian musik karinding merupakan bentukbentuk manifestasi dari kebudayaan, maka keberadannya dituntut untuk senantiasa berubah, berkembang, dan menyesuaikan dengan perkembangan pola pikir atau pandangan masyarakat pendukunganya. Dalam kaitannya dengan hal ini, para praktisi, baik itu pada pegiat seni dan penikmat seni menjadi fondasi utama dalam penjagaan dan pelestarian kesenian tradisional karinding yang ada di Kabupaten Ciamis. Bentuk perubahan atau perkembangan yang ada pada kesenian tradisional karinding Ciamis ada yang bersifat natural atau alami, dalam arti bahwa perubahan yang ada dipengaruhi oleh kondisi alami melalui proses dalam kurun waktu yang relatif lama dengan tidak ada unsur kesengajaan dan tanpa ada tujuan apapun; dan yang bersifat artifisial, dalam arti perubahan yang ada terjadi dalam kurun waktu yang cepat dengan disertai unsur kesengajaan dan mengandung tujuan yang diharapkan adanya bentuk baru dari kesenian tersebut.

Faktor umum terjadinya perubahan kesenian tradisional di Kabupaten Ciamis adalah adanya perubahan pola pikir dan pola sikap kultural yang ada pada masyarakat pedukungnya. Perubahan pola pikir dan pola sikap kultural ini secara tidak langsung telah memengaruhi perkambangan kesenain tradisional yang ada di Ciamis. Dewasa ini, masyarakat daerah, pasca-adanya silang kultural dan komunikasi antarbudaya, telah menyebabkan adanya perubahan pola pikir masyarakat daerah tersebut. Selain itu, ditambah dengan adanya gempuran budaya yang dari luar yang sedikit-banyaknya memengaruhi juga resistensi kultural yang ada pada masyarakat di suatu wilayah tersebut.

Faktor umum yang ada ini kemudian menjadi penyebab juga adanya perubahan yang ada pada internal kesenian tradisional itu sendiri. Faktor umum ini tidak bisa dilepaskan dengan faktor khusus, berupa perubahan pada kesenian tradisional itu sendiri yang pada masanya nanti perubahan-perubahan tersebut menimbulkan adanya kreativitas baru untuk menghasilkan bentuk-bentuk baru dari kesenian tradisional tersebut.

Kedua faktor ini secara langsung memengaruhi tingkat resistensi dan regenerasi kesenian tradisional karinding Ciamis. Adanya perubahan pola pikir pada masyarakat pendukungnya itu, kemudian mengurangi adanya loyalitas kultural yang ada pada masyarakat tersebut, seperti kurangnya minat masyarakat untuk menjaga, mengembangkan, dan melestarikan kesenian tradisional yang ada di tengah-tengah mereka. Sekali lagi, apabila kondisi ini terus dibiarkan, bukan tidak mungkin akan terjadi yang namanya degradasi kultural pada masyarakat tersebut. Degradasi kultural itu sendiri dapat dipahami sebagai bentuk pemerosotan nilai-nilai kultural pada suatu kelompok masyarakat tertentu (Barry \& Partanto, 1994).

Oleh karena itu, tim pengabdian kepada masyarakat memberikan rekomendasi untuk kelestarian karinding, yaitu sebagai berikut: (a) adanya pembinaan sedini mungkin (usia SD) memperkenalkan seni leluhur ini kepada generasi penerus, (b) adanya peran pemerintah berupa peningkatan fasilitas.

Dalam konteks pembinaan sedini mungkin, mesti ada upaya serius dari berbagi pihak, khususnya para praktisi yang berkecimpung di dunia kerajinan tangan untuk berlapang hati mengajarkan kompetensi pembuatan karinding kepada generasi-generasi muda di lingkungan Kabupaten Ciamis. Hal ini menjadi vital adanya, karena pemertahanan seni dan pelestarian seni 
mesti dilakukan dengan adanya pewarisan kompetensi dari generasi tua kepada generasi muda. Selain itu, bukan hanya mengajarkannya, tetapi mesti ada upaya motivasi yang bersifat kultural kepada generasi muda agar mau mempelajari kompetensi kultural tersebut.

Selain itu, mesti ada upaya serius pula dari pihak pemerintahan daerah untuk melestarikan dan menjaga aset intelektual ini. Sebagai pihak yang memiliki wewenang untuk mengambil kebijakan tertentu, pemerintah daerah diharapkan memberikan perhatian lebih untuk melestarikan aset intelektual ini. Ada beberapa hal yang bisa dilakukan oleh pemerintah daerah untuk menjaga dan melestarikan kesenian karinding ini, di antaranya adalah dengan memberikan bantuan dana untuk para pegiat seni yang berkecimpung di dunia kesenian tradisional karinding Ciamis. Selain itu, pemerintah daerah juga bisa membantuk memperkenalkan kesenian tradisional karinding Ciamis ke khalayak umum, bahkan bisa dijadikan sebagai satu di antara barang oleh-oleh pariwisata.

Dalam konteks kebijakan, kesenian tradisional karinding Ciamis mesti dilestarikan dengan menuangkannya ke dalam bentuk tertulis, contohnya buku-buku referensi pembelajaran di sekolah-sekolah. Sebuah buku pembelajaran, khususnya buku pembelajaran bahasa Indonesia tentang sastra, berbasis kearifan lokal karinding Ciamis dapat dibuat dan diajarkan kepada anak-anak didik. Bentuknya merupakan bentuk buku sastra didaktis, karena memuat nilai-nilai kedidaktisan. Solusi penulis untuk masalah ini adalah mesti adanya pengembangan buku cerita anak berbasis kearifan lokal seni musik karinding Ciamis untuk sekolah dasar. Buku cerita anak berbasis kearifan lokal karinding Ciamis mesti dikembangkan dengan adanya penyesuaian karakteristik bahan bacaan cerita anak tersebut.

Seiring perkembangan zaman, terlihat adanya perubahan pola perilaku dan pola budaya yang ada pada masyarakat Ciamis, khususnya dalam konteks pengembangan dan pelestarian kesenian tradisional karinding. Kondisi ini jika terus dibiarkan, sedikitbanyaknya akan mulai menggerus kekayaan intelektual dalam konteks kesenian tradisional di wilayah Ciamis. Dalam konteks lingkungan hidup dan medan sosial seni seperti itu, penulis berusaha memetakan permasalahan kultural yang ada pada daerah tersebut, dan berusaha menawarkan solusi dari ranah penciptaan karya kesenian tradisional yang masih relevan dengan kondisi masyarakat dan kultural yang ada di Ciamis.

Adapun pola pewarisan kesenian tradisional di Ciamis mesti dilakukan dengan sistematis, disengaja, dan komprehensif. Alih generari harus dilakukan dengan baik dan mulus agar proses pewarisan kesenian tradisional tersebut berjalan dengan baik pula. Alih generasi tersebut mesti dilakukan dengan langsung dan disengaja ketika anak-anak diajak dan dilibatkan oleh orang tuanya, sanak saudaranya, atau teman-teman mereka untuk turut menghadiri dan mengikuti proses pembuatan alat musik karinding. Mereka diajak untuk menyaksikan atau berada di dekat proses pembuatan alat musik karinding Ciamis tersebut. Bahkan, mereka harus didudukkan bersama dan berbaur dengan para pelaku seni yang sudah menguasai teori dan praktik proses memainkannya.

Proses pengenalan dan pengajaran kesenian karinding Ciamis ini mesti dilakukan terus-menerus tanpa ada batas waktu atau jenjang. Proses pewarisannya tersebut bisa dilakukan dengan melalui tahapan-tahapan berikut: (1) dimuali dari sebagai orang yang melihat dan menyaksikan proses pembuatan alat musik karinding, (2) beralih untuk mencoba menyertai para praktisi dan pegiat karinding Ciamis pada setiap proses memainkan alat musik tersebut, dan (3) diberikan kesempatan untuk melakukannya sendiri dengan masih ada arahan dan pendampingan dari para pegiat seni senior.

Dalam kaitannya dengan hal tersebut, meminjam istilah formal, bahwa proses pewarisan dan pengajaran kompetensi kesenian tradisional karinding Ciamis mesti dilakukan dengan apa yang disebut proses teaching and learning by doing (mengajar dan belajar sambil bekerja). Maksudnya adalah, bahwa dalam proses pewarisan kompetensi tersebut, mula-mula si pengajar memberikan kompetensi yang bekenaan dengan teori-teori tertentu yang berkaitan langsung dengan pembuatan alat musik karinding Ciamis. Begitu pula dengan subjek didik, mereka bejalar dan memahami teori-teori tersebut dengan sambil praktik dan mengamati langsung di lapangan. Praktik pengajaran seperti ini akan lebih mudah untuk dikuasai.

Meskipun proses pewarisannya tidak dalam kaitannya dengan praktik pewarisan formal atau hanya sambil lalu, jika diamati dengan seksama, tampak bahwa metode pewarisan seperti ini justru lebih efektif dan akan mencapai sasaran tujuan yang hendak dicapai. Dari pengamatan peneliti, para pegiat seni karinding senior yang bertindak sebagai sumber belajar ini terlihat sering menggunakan metode pelaziman dan imitasi atau peniruan. Akan tetapi, yang masih menjadi kendala adalah minat dan ketertarikan para generasi muda untuk menggeluti kesenian tradisional karinding Ciamis ini masih sangat minim, sehingga proses pewarisan dan regenerasi kompetensinya juga sedikit terkendala.

Yang dimaksud dengan proses pewarisan dengan metode pelaziman dalam proses regenerasi kesenian tradisional karinding Ciamis ini adalah suatu cara membawa anak-anak (generasi muda) untuk mengenal, menyenangi, dan mencoba pekerjaan melalui proses pembiasaan, yang diajarkan dan dikenalkan oleh para orang tua (generasi tua), para pegiat seni senior, atau para praktisi langsung dari kesenian tradisional karinding Ciamis ini. Oleh pada generasi tua (orang tua, perajin senior, dan para praktisi seni), anak-anak dan generasi muda dibiasakan untuk akrab dengan lingkungan pekerjaan orang tuanya. Jika hal ini terus dilakukan dengan berkesinambungan, sejak dini anak-anaknya akan akan terbiasa melihat dan 
menyaksikan bahkan mengikuti apa yang sering dilakukan oleh orang tuanya.

Metode pelaziman dan imitasi langsung ini akan berlangsung secara terus-menerus dalam kurun waktu yang relatif lama, sehingga pada masanya nanti anakanak dan generasi muda akan mengurusi dirinya dengan mandiri, sehingga membentuk suatu sikap dan pola kelakukan yang mentradisi sebagai suatu gaya hidup berkesinambungan, yakni sebagai seorang pegiat kesenian tradisional karinding Ciamis.

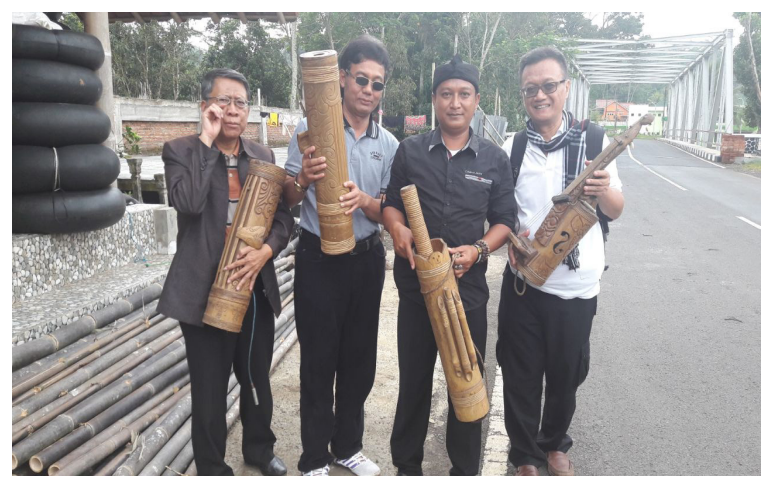

Gambar 1. Dokumentasi Peneliti Bersama Perajin Karinding

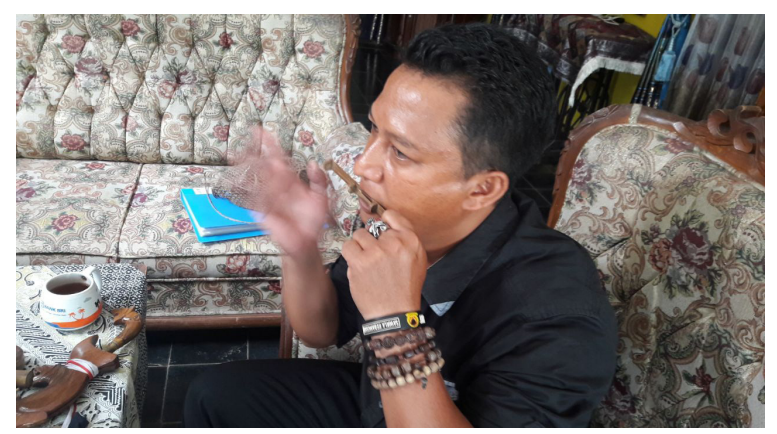

Gambar 2 Cara Memainkan Karinding Sumber: dokumentasi peneliti 2019

\section{SIMPULAN}

Seni tradisional karinding merupakan satu di antara kesenian andalan yang lahir dan berkembang di daerah Kabupaten Ciamis. Eksistensi dan keberadaan kesenian tradisional karinding dewasa ini sudah semakin sulit ditemukan. Sebagai satu di antara kerajinan tangan tradisional ikonik Kabupaten Ciamis, karinding harus terus dijaga dan dilestarikan. Keberadannya sebagai aset intelektual yang berhubungan dengan pengetahuan tradisional, kerajinan tangan ini sedikit-banyaknya telah memberikan sumbangsih kultural dalam meningkatkan daya tarik wisata (khususnya dalam hal penyediaan souvenir), ekonomis, dan kultural di Kabupaten Ciamis. Rekomendasi untuk kelestarian karinding, yaitu sebagai berikut: (a) adanya pembinaan sedini mungkin (usia SD) memperkenalkan seni leluhur ini kepada generasi penerus, (b) adanya peran pemerintah berupa peningkatan fasilitas.

\section{DAFTAR PUSTAKA}

Barry, \& Partanto. (1994). Kamus Ilmiah Populer. Surabaya: Arkola.

Gunardi, G. (2014). Peran Budaya "Mikanyaah Munding" Dalam Konservasi Seni Tradisi Sunda. Panggung, 24, (4), 329-334. https://doi.org/10.26742/ panggung.v24i4.129

Sedyawati, E. (2006). Budaya Indonesia, Kegiatan Arkeolog, Seni dan Sejarah. Jakarta: Grafindo Persada.

Sumardjo, J. (2006). Estetika Paradoks. Bandung: STSI.

Susanto, A. S. (1983). Pengantar Sosiologi dan Perubahan Sosial. Jakarta: Binacipta.

Wikandia, R. (2016). Pelestarian dan Pengembangan Seni Ajeng Sinar Pusaka pada Penyambutan Pengantin Khas Karawang. Panggung, 26, (1), 58-69. https:// doi.org/10.26742/panggung.v26i1.162 